DOI https://doi.org/10.30525/978-9934-26-038-4-27

\title{
ОСОБЛИВОСТІ РЕГІОНАРНОГО КРОВООБІГУ У ХВОРИХ НА ГАСТРОЕЗОФАГЕАЛЬНУ РЕФЛЮКСНУ ХВОРОБУ ІЗ СУПУТНІМ ОЖИРІННЯМ
}

\author{
Маляр О. М. \\ аспірантка кафедри терапї̈, ревматології та клінічної фармакології \\ Харківська медична академія післядипломної освіти \\ Опарін А. Г. \\ доктор медичних наук, Заслужений лікар Украӥни, \\ професор кафедри терапії, ревматології та клінічної фармакології \\ Харківська медична академія післядипломної освіти
}

\section{Опарін О. А.}

доктор медичних наук професор, завідувач кафедри терапії, ревматології та клінічної фармакології

Харківська медична академія післядипломної освіти

Хоменко Л. О.

кандидат медичних наук,

доцент кафедри терапї, ревматології та клінічної фармакології

Харківська медична академія післядипломної освіти

м. Харків, Україна

Гастроезофагеальна рефлюксна хвороба (ГЕРХ) - одне з найрозповсюдженіших захворювань у практиці лікаря загальної практики, однак діагностика може викликати труднощі. Провідним фактором розвитку ГЕРХ являється ожиріння. Вісцеральна жирова тканина призводить до підвищення внутрішньошлункового тиску та збільшення градієнта тиску між шлунком і стравоходом, сповільнення евакуаторно-моторної функції верхніх відділів шлунково-кишкового тракту $[1,2,3]$. Також ожиріння сприяє прогресуванню гастроезофагеального рефлюксу та пришвидшує розвиток ускладнень, що і обумовлює актуальність проблеми та вимагає розробки удосконадених методів діагностики та лікування.

Мета: дослідити особливості регіонарного кровообігу у хворих на гастроезофагеальну рефлюксну хворобу. 
Матеріали та методи: Обстежено 50 пацієнтів: 24 (48\%) жінок та $26(52 \%)$ чоловіків віком від 18 до 24 років (середній вік - 21 $\pm 2,5$ років). Критеріями вилучення були: супутня патологія (окрім ожиріння), захворювання щитовидної залози, ендокринні форми ожиріння, вагітність, ускладнені форми ГЕРХ. Здійснено ретельне опитування щодо наявних скарг, зібрано повний анамнез захворювання та життя, проведено фіброгастродуоденоскопію, pН-метрію, рентгенографію. Також проводилося анкетування за допомогою опитувальника GERDQ.

Діагноз ГЕРХ встановлено згідно МКХ-10, рекомендацій клініки Мейо і Монреальського всесвітнього консенсусу 2006 року, на підставі скарг (печія, відрижка, регургітація один і більше разів на тиждень протягом останніх півроку), даних інструментальних досліджень та опитування. Надлишкову масу тіла визначали за допомогою IMT (відношення маси тіла до зросту у квадраті). Значення вище 30 було підставою для встановлення ожиріння.

Пацієнтів було розподілено на 3 групи: 1 група включала 16 хворих на ГЕРХ із супутнім одирінням, 2 група включала 19 хворих на ГЕРХ без супутньої патології та 3 група - 15 практично здорових осіб.

Стан регіонарного кровотоку досліджували за швидкостю кровотоку і діаметру черевного стовбура (ЧС), методом імперсно-хвильової доплерографії з кольоровим картуванням, виконаної на ультразвуковому апараті Aloka-SSD-650 (виробництво Японія). Статистичну обробку даних проводили за допомогою програм Microsoft Office Excel 2007 та Statistica 6.0.

Результати. Спостерігалося достовірне зниження діаметра черевного стовбуру у I групі в середньому до $0,8 \pm 0,11 \mathrm{~cm}$, у II групі до $0,85 \pm$ 0,10 см. У контрольній групі діаметр черевного стовбура становив 0,98 $\pm 0,12$ см $(\mathrm{p}<0,05)$. Фіксувалося зниження швидкості кровотоку в черевному стовбурі у I групі в середньому до $11,2 \pm 0,5 \mathrm{~cm} / \mathrm{c}$, у II групі - у середньому до 12,4 \pm 0,64 cм/с . У контрольній групі швидкість кровотоку дорівнювала $14,4 \pm 0,9 \mathrm{~cm} / \mathrm{c}(\mathrm{p}<0,05)$. Встановлено, що показники діаметра черевного стовбура та швидкості кровотоку в ньому у хворих на ГЕРХ із супутнім ожирінням були достовірно нижчими за хворих без супутньої патології.

Висновки. Встановлено достовірне зниження показників регіонарного кровотоку у хворих на ГЕРХ із супутнім ожирінням порівняно із групою хворих на ГЕРХ без супутньої патології та контрольною групою. Виявлено кореляційну залежність між IMT, вираженістю клінічної картини та показниками регіогарного кровотоку. Результати даного дослідження мають практичну значимість і сприятимуть удосконаленню методів патогенетичного лікування. 


\section{Література:}

1. Wu Y.W., Tseng P.H., Lee Y.Ch., Wang S.Y., Chiu H.M., Tu C.H, Wang H.P., Lin J.T., Wu M.S., Yang W.S. Association of Esophageal Inflammation, Obesity and Gastroesophageal Reflux Disease: From FDG PET/CT Perspective. PLoS One. 2014. 9(3). URL: http://dx.doi.org/10.1371/ journal.pone.0092001.

2. Бабак М.О. Гастроезофагеальна рефлюксна хвороба в поєднанні 3 ожирінням: клініко-патогенетичні особливості, епідеміологічний аналіз та прогнозування перебігу: автореф. дис. ... канд. мед. наук: 16.01.02. Луганськ, 2011. 20 с.

3. Nocon M., Labenz J., Jaspersen D., Meyer-Sabellek W., Stolte M., Lind T., Malfertheiner P., Willich S.L. Association of body mass index with heartburn, regurgitation and esophagitis: result of the Progression of Gastroesophageal Reflux Disease stady. Journal of Gastroenterology and Hepatology. 2007. № 22. P. 1728-1731. Doi: 10.1111/j.1440-1746. 2006.04549.x.

4. Звенигородская Л.А., Бондаренко Е.Ю. Клиникоморфологические особенности гастроэзофагеальной рефлюксной болезни у пациентов с абдоминальным ожирением. Consilium medicum Ukraina. 2012. Том. 7. № 6. С. 3 - 7.

5. Boeckxstaens G, El-Serag H.B., Smout A.J.P.M., Kahrilas P.J. Symptomatic reflux disease: the present, the past and the future. BMJ. 2014. № 63(7). P. 1185-1193. Doi: 10.1136/gutjnl-2013-306393

6. Singh M., Lee J., Gupta N., Gaddam S., Smith B.K., Wani S.B., Sullivan D.K., Rastogi A., Bansal A., Donnelly J.R., Sharma P.Weight loss can lead to resolution of gastroesophageal reflux disease symptoms: A prospective intervention trial. Obesity. 2013. Vol.21. P. 284-290. Doi: 10.1002/oby.20279.

7. Metlakunta A. S. Neuronal suppressor of cytokine signaling-3 deficiency enhances hypothalamic leptin-dependent phosphatidylinositol 3-kinase signaling. The American Journal of Physiology-Regulatory, Integrative and Comparative Physiology. 2011. V.18. P.1185-1193. URL: https://doi.org/10.1152/ajpregu.00794.2010

8. Vakil N., van Zanten S.V., Kahrilas P., Dent J., Jones R. The Montreal definition and classification of gastroesophageal reflux disease: a global evidence-based consensus. Am. J. Gastroenterol. 2006. № 101. P. 1900-1920. URL: http://dx.doi.org/10.1111/j.1572-0241.2006.00630.x 